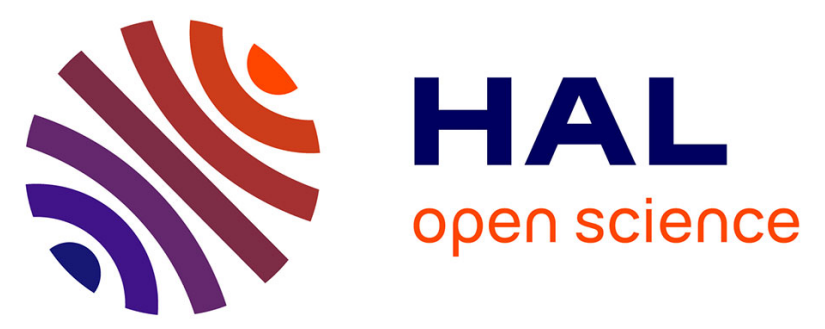

\title{
Fate and impacts of pharmaceuticals and personal care products after repeated applications of organic waste products in long-term field experiments
}

Marjolaine Deschamps, Sabrina Ferhi, Nathalie Bernet, Frederic Feder, Olivier Crouzet, Dominique Steyer, Denis Montenach, Géraud Daniel Moussard, Vincent Mercier, Pierre Benoit, et al.

\section{To cite this version:}

Marjolaine Deschamps, Sabrina Ferhi, Nathalie Bernet, Frederic Feder, Olivier Crouzet, et al.. Fate and impacts of pharmaceuticals and personal care products after repeated applications of organic waste products in long-term field experiments. Science of the Total Environment, 2017, 607-608, pp.271-280. 10.1016/j.scitotenv.2017.06.240 . hal-01570307

\section{HAL Id: hal-01570307 \\ https://hal.science/hal-01570307}

Submitted on 26 May 2020

HAL is a multi-disciplinary open access archive for the deposit and dissemination of scientific research documents, whether they are published or not. The documents may come from teaching and research institutions in France or abroad, or from public or private research centers.
L'archive ouverte pluridisciplinaire HAL, est destinée au dépôt et à la diffusion de documents scientifiques de niveau recherche, publiés ou non, émanant des établissements d'enseignement et de recherche français ou étrangers, des laboratoires publics ou privés.

\section{다(1)(2)}

Distributed under a Creative Commons Attribution - ShareAlikel 4.0 International 


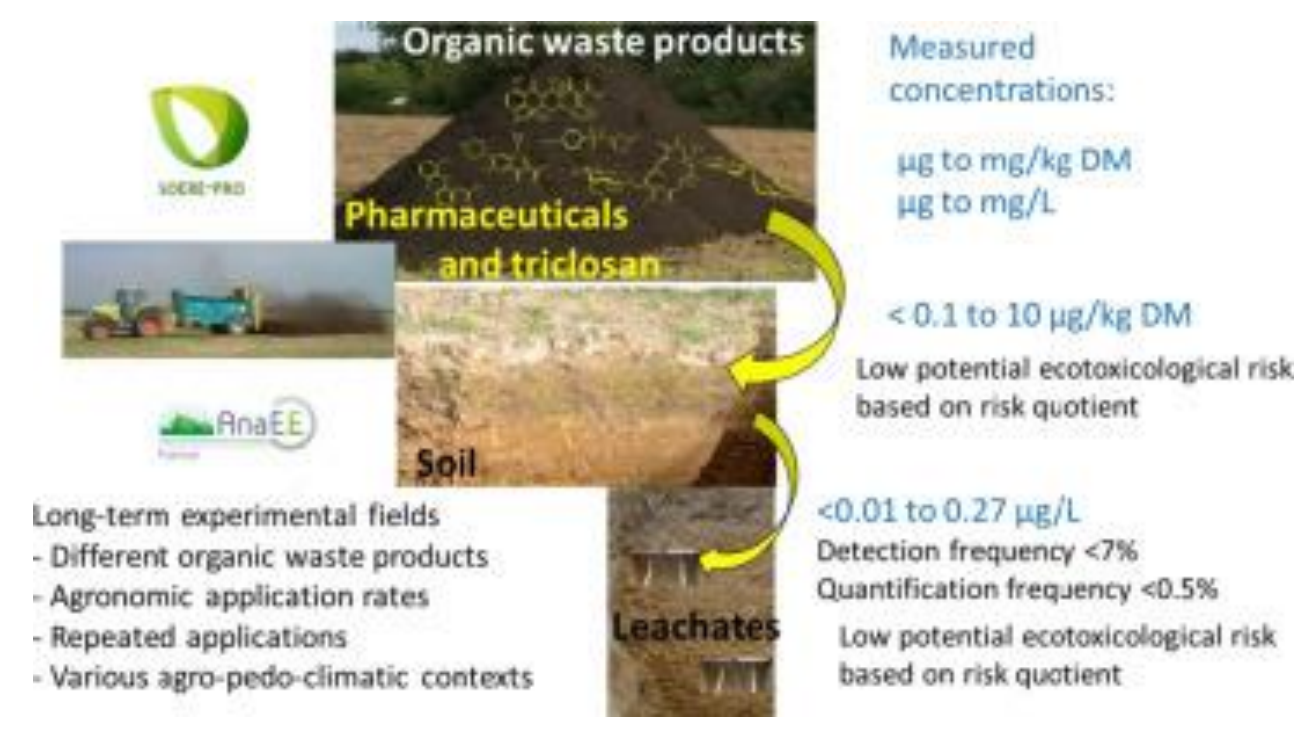

Marjolaine Bourdat-Deschamps, Sabrina Ferhi, Nathalie Bernet, Fréderic Feder, Olivier Crouzet, Dominique Patureau, Denis Montenach, Géraud D. Moussard, Vincent Mercier, Pierre Benoit, Sabine Houot

Fate and impacts of pharmaceuticals and personal care products after repeated applications of organic waste products in long-term field experiments

Science of The Total Environment, Volumes 607-608, 2017, 271-280

http://dx.doi.org/10.1016/j.scitotenv.2017.06.240 